\title{
Coppiced hardwood trees for reuse of farm dairy effluent
}

V.O. SNOW ${ }^{1}$, L.E. FUNG ${ }^{1}$, S.E. HURST ${ }^{1}$, I.R. MCIVOR ${ }^{1}$, G.B. DOUGLAS ${ }^{2}$, A.G. FOOTE ${ }^{2}$, J.D. ARNOLD ${ }^{3}$ and P.N. CAMERON ${ }^{4}$

${ }^{1}$ HortResearch, Private Bag 11030, Palmerston North

${ }^{2}$ AgResearch, Private Bag 11008, Palmerston North

${ }^{3}$ Armagh Farms, Jervois Road, Carterton

${ }^{4}$ Greater Wellington Regional Council, PO Box 41, Masterton

VSnow@ hortresearch.co.nz

\begin{abstract}
Alternatives to the traditional treatment of effluent, irrigation back onto pasture, may prove valuable for farmers. Here we present the results from the first two years of a trial set up to test the potential of cut-and-carry coppiced hardwoods (poplars and willows) in taking up nitrogen from fresh effluent and providing fodder on a dairy farm. Three blocks each of Argyle poplars and Tangoio willows were planted as $1.2 \mathrm{~m}$ stakes on a dairy farm in southern Wairarapa in September 2001. One block of each species was irrigated with fresh farm dairy effluent at a high rate, about $5 \mathrm{~mm}$ per week, the second was irrigated at a low rate of about half that amount, and the third control block of each species was left unirrigated.
\end{abstract}

The first coppicing, conducted in March 2002, yielded 6, 13, and $24 \mathrm{t} \mathrm{DM/ha} \mathrm{from}$ the Willow-Control, -Low, and -High treatments. The corresponding yields from the poplar blocks were 6,14 , and $11 \mathrm{t} \mathrm{DM/ha}$. The depressed yield of the PoplarHigh was due to a rust infection. Growth was much slower in 2002/03 due to a cold October and dry summer. The yields were about a third of those measured in the previous year. The amount of nitrogen in the harvested biomass of the WillowHigh treatment was 440 and $100 \mathrm{~kg} \mathrm{~N} / \mathrm{ha}$ in the two years.

Coppice blocks are likely to be most useful where the amount of land suitable for irrigation is limited, where there may be heightened concerns about the effects of nitrate leaching, or where wet weather storage of effluent is limited. The coppice blocks accumulate a large amount of animal fodder in late summer when many farms experience feed gaps and the fodder from coppice blocks may also have animal health benefits.

Keywords: willow, poplar, forage crops

\section{Introduction}

Many aspects of dairy farming have come under increasing environmental scrutiny and in recent years the effect of farm dairy effluent has been of particular concern to the public and Regional Councils. These concerns are heightened where farms 
are established alongside waterways that flow into significant catchments or where tile drainage systems can quickly move drainage water from paddocks to waterways. Farm dairy effluent is often irrigated onto pasture. This is a practice that is either encouraged or required by Regional Councils. When done appropriately for the soil, pasture, and weather conditions, irrigation onto pasture provides a source of nutrients for the pasture (Longhurst et al. 1999) and renovates the effluent by removing nitrogen and other nutrients and allowing sufficient passage of time that pathogens are killed so that any drainage will not have undue adverse effects on the environment. For the effluent to successfully renovated it must be applied correctly. Correct application means ensuring that the amount of effluent applied is within the capacity of the pasture-soil system to process it, ensuring that there is no runoff or local ponding and that the effluent is not applied when the soil is too wet, and ensuring that the soil surface does not become sealed. If effluent is applied incorrectly, the concentration of nitrate in the drainage from the irrigated pastures can rise to unacceptable levels (Logan 1993). In turn, this leads to contamination of groundwater or, in the case of tile drained systems, surface water (Williamson et al. 1998).

Poplars and willows are used extensively in New Zealand for soil conservation and riverbank plantings (Wilkinson 1999), because of their ability to grow quickly in wet areas, establish extensive root systems, and remove large amounts of water (Guevara-Escobar et al. 2000). In addition, their ability to coppice repeatedly makes them promising candidates for use in effluent irrigated systems; either as vegetation to be directly irrigated by the effluent, or as riparian buffer zone plantings to capture nitrogen from seepage or re-irrigated tile drainage. A further advantage of the trees is that the foliage can be cut and fed to stock (Oppong et al.2001, Kemp et al. 2001), either milking or dried-off cows, or other livestock systems.

The aim of this study was to explore the possibilities for using coppiced poplars and willows in effluent irrigated systems. A "proof-of-concept" demonstration trial of poplars and willows irrigated with dairy shed effluent was established in southern Wairarapa. This paper describes the trial design, and gives early results from the first two years of the trial. The primary objective of the trial was to determine the potential growth rate and nitrogen uptake of the trees under effluent irrigation.

\section{Materials and methods}

\section{Species and experimental design}

The trial was established on a commercial dairy farm near Carterton in southern Wairarapa. The soil at the trial site is a gravelly ( $35 \%$ gravel below $0.1 \mathrm{~m})$ silt loam and is excessively well drained. Ground preparation (ripping and pre-plant spraying with $3.6 \mathrm{ml}$ Glyphospate and $10 \mathrm{ml}$ Terbuthylazine per litre water applied to the pre- 
existing pasture to the point of runoff) was done on 12 September 2001 and $1.2 \mathrm{~m}$ stakes were planted to a depth of $0.5 \mathrm{~m}$ during the week of 17-21 September 2001. The two trees species in the trial are 'Argyle' poplar (Populus deltoides $\mathrm{x}$ P. nigra) and 'Tangoio' willow (Salix matsudana x $S$. alba). Two blocks of each species were planted to allow testing of two effluent application rates. In addition there are small willow and poplar blocks that receive no effluent as control comparisons. Within each, unreplicated, planting block there are four beds $3 \mathrm{~m}$ wide with a $3 \mathrm{~m}$ vehicle space between beds. Trees were planted at $1 \mathrm{~m}$ spacings across the bed and $0.75 \mathrm{~m}$ along the bed. Pasture plots were also established as comparisons to the tree plots. Monitoring of the pasture began later than on the tree plots and there are, as yet, insufficient results to report here. Figure 1 shows the planting plan.

Figure 1. Trial layout.

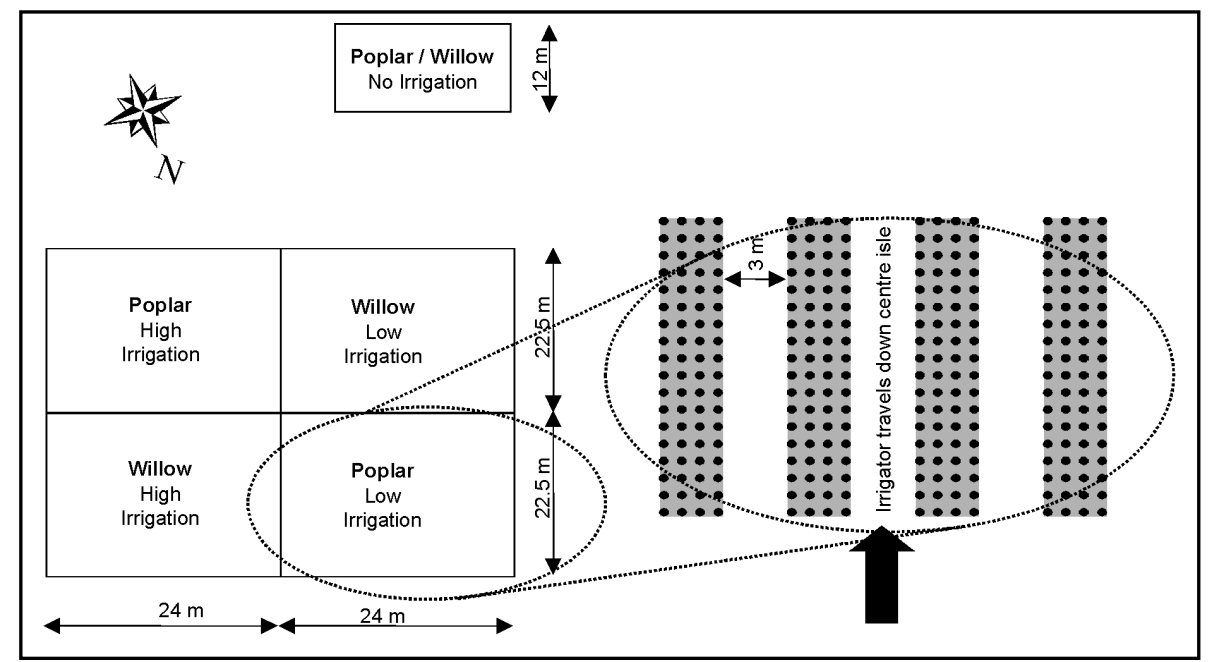

\section{Effluent application}

Irrigation began in late November 2001 and, in the first season, continued until late March 2002. Irrigation in the second season was applied from early November 2002 to mid-January 2003 and then from mid-February to late April 2003. The trees were irrigated with fresh effluent by a travelling irrigator that was set up to move down the centre aisle of each planting block. The high treatment received about $5 \mathrm{~mm}$ per week and the low treatment half that amount. The frequency of irrigation was dependent on the runoff from the milking shed, but in dry periods the irrigation cycle was completed in 7-10 days. The concentration of nitrogen in the effluent was not measured but if a typical concentration of about $300 \mathrm{mg} \mathrm{N} / \mathrm{L}$ (Williamson et al. 1998) were assumed then these irrigation rates would apply about 250 and $500 \mathrm{~kg} \mathrm{~N} / \mathrm{ha} / \mathrm{yr}$ to the plots. 


\section{Tree management and measurement}

The trees were first coppiced between 23 and 27 March 2002 using a chainsaw to cut the trees to a height of $0.1 \mathrm{~m}$. Immediately prior to coppicing, three sub-plots of four trees were selected from the centre of the beds nearest to the irrigator run in each block. Sub-plots were chosen at random locations in the control plots. The sub-plot trees were tagged, cut at $0.1 \mathrm{~m}$ above ground level, and retained for dissection. The remaining trees in the plots were cut at a similar height and fed whole to the milking herd. Following measurement of individual tree height, each of the tagged trees was dissected into "leaf" (lamina, petiole, and the small side stems generally less than about $2 \mathrm{~mm}$ diameter and easily stripped by running a hand down the stem), "edible" stem of less than $5 \mathrm{~mm}$ diameter (Kemp et al. 2001), and large woody stem material. The resulting botanical components were bulked across trees within sub-plots. Fresh weights were taken and sub-samples ovendried for 48 (leaves and edible stem) to 96 (large stem) hours at $70^{\circ} \mathrm{C}$ to determine dry matter. Subsamples of each component were ground to $<1 \mathrm{~mm}$ and analysed for total nitrogen concentration with a LECO CN analyser. In this first year tree growth was sufficient to prevent any significant weed regrowth.

The second coppice was done on 4 February 2003. A sub-plot of trees in each of the irrigated treatments was retained for cutting later in the season and four trees per plot were retained for biomass analysis. These trees were processed as described for the first coppice except that they were freeze-dried rather than oven dried due to a change in the availability of equipment. A scrub cutter was used to cut the remaining stems to a height of $0.1 \mathrm{~m}$. The stems were fed through a mulcher and into a silage wagon before being fed to the milking cows in another paddock. In this second year there was significant weed growth but because the weeds would not normally be included in the material removed from the site their growth and contribution to nitrogen uptake was not quantified. The trees that were left standing from the February harvest were cut by hand on 10 April 2003 and were processed to determine their total dry weight. There were no trees to be harvested in the control plots at this time.

\section{Results and discussion}

Growth in the 2001/02 season

Growth in this first year was rapid. The irrigated trees closed canopy by January 2002 and two months later, when the trees were harvested, many were over $3 \mathrm{~m}$ tall (Table 1). There was a dramatic response to irrigation as shown by the relative size and biomass of the control and irrigated trees (Figures 2 and 3). There was no regrowth from the stumps before winter 2002 .
Table 1. Tree height at coppicing in March 2002 and February 2003.

\begin{tabular}{llcc}
\hline & & \multicolumn{2}{c}{---- Height $(\mathrm{m})$--.- } \\
& & Mar-02 & Feb-03 \\
\hline Poplar & Control & 1.8 & 1.6 \\
& Low & 3.0 & 1.7 \\
& High & 2.9 & 1.9 \\
Willow & Control & 1.9 & 1.7 \\
& Low & 2.5 & 1.9 \\
& High & 2.9 & 2.1 \\
\hline
\end{tabular}


Figure 2. Relative size of the poplar trees when they were first coppiced in March 2002 and at the second coppice in February 2003.
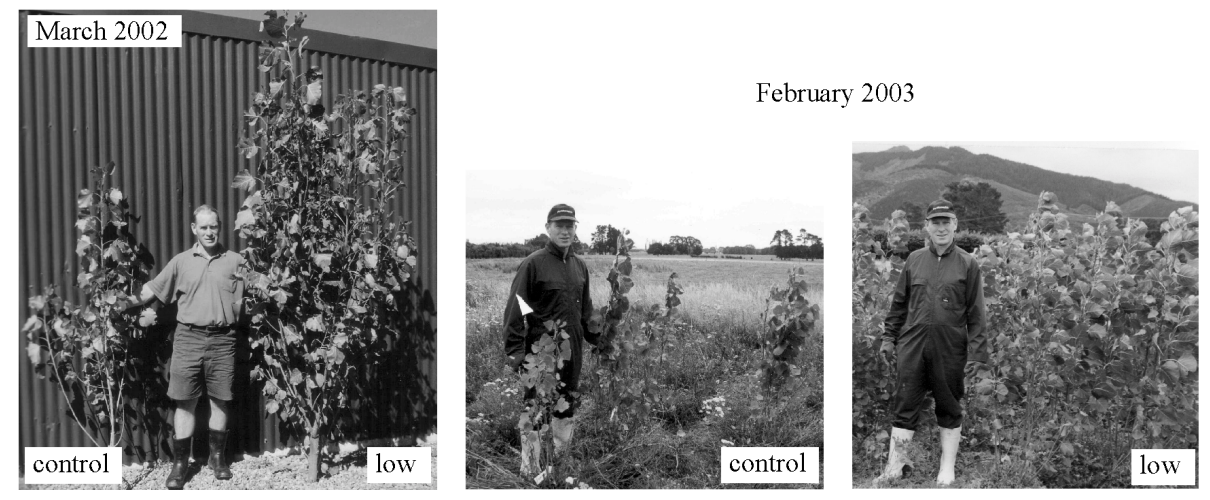

Figure 3. Tree biomass harvested April 2002 and again in February and April 2003. The bars show the mean biomass harvested and the error bars indicate the maximum of the 3 (2002) or 4 (2003) samples.

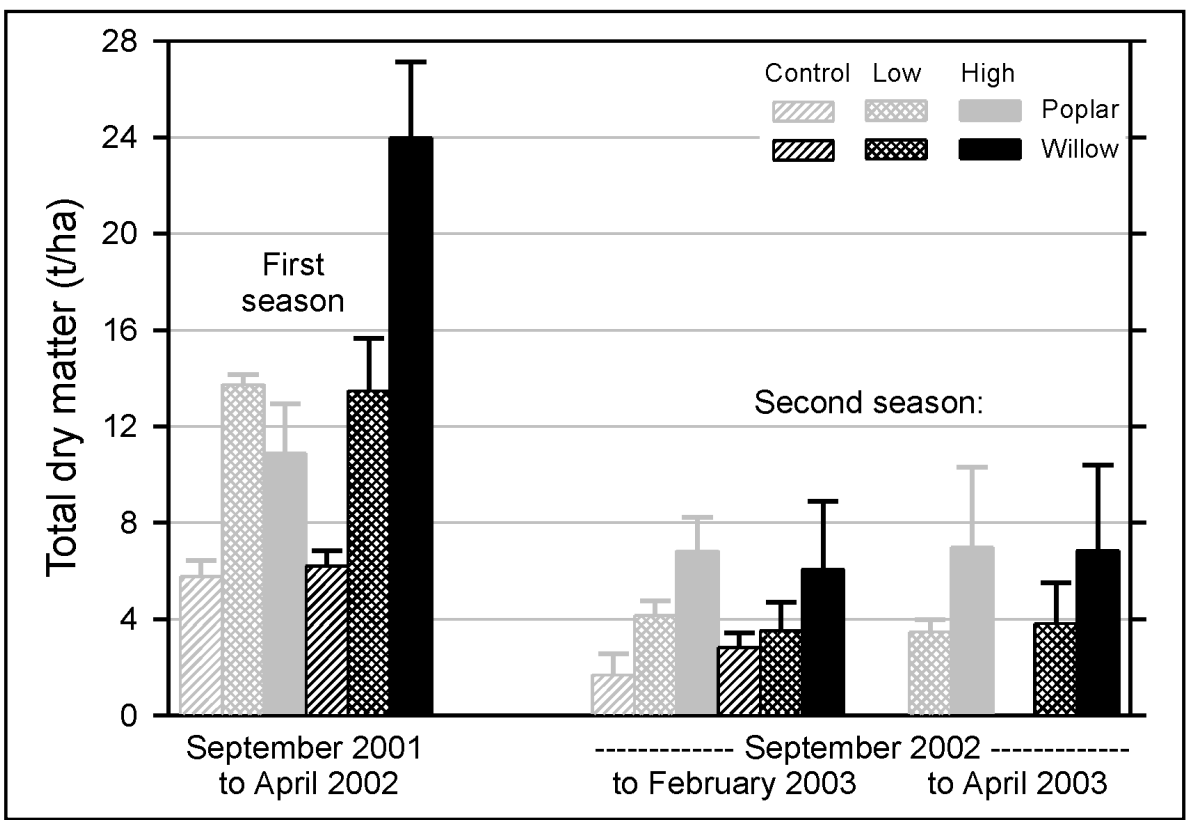


The unirrigated willows produced $6 \mathrm{t} \mathrm{DM} / \mathrm{ha}$ while the Willow-Low treatment produced twice that, $13 \mathrm{t} \mathrm{DM} / \mathrm{ha}$. The Willow-High treatment showed the greatest accumulation of dry matter with $24 \mathrm{t} \mathrm{DM} /$ ha accumulated in the seven months following planting (Figure 3). Given that the trees were growing from stakes and that a relatively small amount of irrigation was applied, such a large response to effluent irrigation was not expected in the first year. However, it is likely that the wet summer of 2001/02 provided sufficient water to allow the trees to take advantage of both the nitrogen applied in the effluent and mineralised from the sprayed pasture.

Trees in the Poplar-Control and Poplar-Low treatments showed similar growth to the equivalent willow treatments, but the Poplar-High treatment grew about $80 \%$ of the biomass accumulated by the Poplar-Low treatment. It is likely that the depressed biomass in the Poplar-High was due to heavy rust infestation facilitated by the moist conditions (high rainfall and regular overhead irrigation) during much of the growing season. We observed that a considerable amount of leaf had been dropped, particularly from the Poplar-High treatment between the 7th of March and the sampling on the 21st of March.

\section{Growth in the 2002/03 season}

Approximately the same relative growth patterns were observed between the treatments in 2002/03 as in the previous year (Figure 3). The exception to this was the Poplar-High treatment, which did not show any depression of biomass compared to the Poplar-Low as observed in the first year. There was no significant rust observed when the trees were harvested in February 2003, but rust had affected both the Poplar-Low and Poplar-High treatments by April 2003. Due to the time taken for the infection process, younger leaves are less affected by rust than older leaves, so time of coppicing may be an effective tool for managing rust in susceptible clones in effluent-irrigated blocks.

In contrast to 2001/02, growth during 2002/03 was slow, with the shoots appearing later than expected. By December 2002 the trees (with an established root system) had a lower leaf area than they had in December 2001, when they were growing from unrooted stakes.

Spring 2002 was a difficult season for growth. In particular October was cold. Using meteorological data from the NIWA East Taratahi station (about $10 \mathrm{~km}$ from the trial site), the average daily minimum temperature was $2^{\circ} \mathrm{C}$ below normal for the month. There were 13 ground frosts rather than the usual four (Table 2). New shoots were probably killed or severely damaged by these frosts, so delaying growth further into the season than usual. October was also a dry month but this unlikely to have adversely affected the trees because they had few leaves at that time. 
Table 2. Rainfall and daily minimum temperature during the growing season using data from the NIWA Masterton meteorological site.

\begin{tabular}{lcccccc}
\hline & \multicolumn{3}{c}{$-\cdots$} & \multicolumn{3}{c}{ Average minimum temperature (C) } \\
& Average & 2001/02 & 2002/03 & Average & 2001/02 & 2002/03 \\
\hline September & 65 & 20 & 55 & 5 & 3 & 5 \\
October & 72 & 99 & 36 & 7 & 8 & 4 \\
November & 82 & 101 & 80 & 7 & 9 & 8 \\
December & 58 & 176 & 45 & 10 & 12 & 10 \\
January & 59 & 62 & 39 & 11 & 11 & 10 \\
February & 55 & 59 & 30 & 9 & 9 & 10 \\
March & 72 & 45 & 20 & 7 & 6 & 10 \\
April & 77 & 54 & 35 & & & 7 \\
Season total & 540 & 616 & 340 & & & 9 \\
\hline
\end{tabular}

From December 2002 onwards rainfall was low, about half the average rainfall (Table 2). The stoney soil at the site stores little plant-available water and so exacerbated the effects of the low rainfall. Evaporative demand was calculated as 0.75 of the reference crop evaporation (Smith et al. 1992) using the meteorological data from the East Taratahi station. Between October 2002 and March 2003 inclusive the evaporative demand averaged $23 \mathrm{~mm} /$ week. Although the trees were irrigated, the high application rate (about $5 \mathrm{~mm} /$ week), was not nearly enough when compared to the evaporative demand to provide sufficient water for the high growth rates seen in 2001/02. While irrigation with water would increase tree growth under these conditions on most farms this would be impracticable.

Due to the low spring temperatures and the low summer rainfall, tree growth was considerably less in 2002/03 than in 2001/02 (Figure 3). Two months after cutting, in April 2003, the regrowth was about $0.4 \mathrm{~m}$ high.

\section{Nitrogen}

Leaf nitrogen concentration varied between 2.3 and $3.7 \%$ (Table 3 ) and in all years and treatments showed a trend of increasing concentration with increasing effluent application. These concentrations are within the range measured by Oppong et al. (2001) on a rather lowfertility flat site $(2.5-3.2 \% \mathrm{~N})$ but are somewhat lower than
Table 3. Leaf nitrogen concentration measured in the two seasons.

\begin{tabular}{|c|c|c|c|}
\hline \multirow[b]{2}{*}{ Species } & \multirow[b]{2}{*}{ Irrigation } & \multicolumn{2}{|c|}{ Leaf nitrogen concentration (\%) } \\
\hline & & $2001 / 02$ & $2002 / 03$ \\
\hline \multirow[t]{3}{*}{ Poplar } & Control & 3.0 & 2.3 \\
\hline & Low & 3.5 & 3.1 \\
\hline & High & 3.7 & 3.5 \\
\hline \multirow[t]{3}{*}{ Willow } & Control & 2.4 & 2.5 \\
\hline & Low & 2.7 & 3.0 \\
\hline & High & 2.8 & 3.2 \\
\hline Standard error & 0.09 & 0.06 & \\
\hline
\end{tabular}


the 4\% N measured by Elowson (1999). Elowson's measurements were made on fully-expanded young leaves rather than the whole-canopy average measured here. In addition we used a definition of "leaf" that included petiole and small side stems whereas Elowson did not. At the plot edges, where penetration of the irrigation diminished, there were visible transects of increasing nitrogen deficiency in the leaves. Given that no plateau of nitrogen concentration was observed with increasing amount of nitrogen applied, it may be that greater nitrogen availability would lead to higher leaf nitrogen concentrations. Typical nitrogen concentrations of the edible stem and large stem were 1.1 and $0.6 \%$.

In the first season $440 \mathrm{~kg} \mathrm{~N} / \mathrm{ha}$ was harvested and removed from the Willow-High treatment. In contrast, only $148 \mathrm{~kg} \mathrm{~N} / \mathrm{ha}$ was removed from the Poplar-High, because of the rust-induced yield depression, but we estimated that $365 \mathrm{~kg} \mathrm{~N} / \mathrm{ha}$ might have been harvested had the expected relative growth rates held true for 2001/02. In 2002/03, the amount of N removed from the plots was only 97 and $134 \mathrm{~kg} \mathrm{~N} / \mathrm{ha}$ for the Willow-High and Poplar-High treatments. We suggest that in these two years we have captured the extremes of probable long-term performance of the coppice blocks at this site.

As these coppice blocks are alternatives to irrigating the effluent onto grazed pasture it would be illustrative to compare the figures above to the nitrogen balance of irrigated pasture (Table 4). Because of the year-round growth of pasture, the amount of nitrogen in the biomass eaten by cows is likely to be higher than the amount of nitrogen in the biomass that can be harvested from the deciduous coppice blocks. However, in grazed pastures, $70 \%$ of the consumed nitrogen is deposited back onto the pasture in the form of dung and urine (Whitehead 1995) so the net removal is in the order of $150 \mathrm{~kg} \mathrm{~N} / \mathrm{ha} / \mathrm{yr}$. Regional Councils generally allow between 150 and $200 \mathrm{~kg} \mathrm{~N} / \mathrm{ha} / \mathrm{yr}$ in effluent to be applied (Heatley 1995). Based on the industry standard of $6 \mathrm{~kg} \mathrm{~N} / \mathrm{cow} / \mathrm{yr}$ in the effluent (Heatley 1995), 4 ha is required per 100 cows. In the absence of other information we have assumed that there are $10 \%$ harvesting losses from the coppice blocks so most of the nitrogen is removed from the site resulting in between 1.5 and 6.7 ha being required per 100 cows. If the pasture were managed as a cut and carry system, for example in continuous silage,

Table 4. Calculations comparing the area needed per 100 cows for a typical grazed pasture and the likely range of harvested coppice blocks.

\begin{tabular}{lccc}
\hline & Typical pasture & -......- Coppice block -....-.- \\
& & Low range & High range \\
\hline Harvestable biomass (t DM /ha /yr) & $12-18$ & 7 & 24 \\
$\mathrm{~N}$ in biomass (kg N /ha /yr) & 500 & 100 & 440 \\
Returned to site (kg N /ha /yr) & 350 & 10 & 44 \\
Removed from site (kg N /ha /yr) & 150 & 90 & 400 \\
Area need per 100 cows (ha) & 4.0 & 6.7 & 1.5 \\
\hline
\end{tabular}


then it is likely that such a system would remove more nitrogen than a coppice system however such systems are not in wide use in the industry.

\section{Fodder value}

Observations of dry dairy cows have shown that they will vigorously browse on standing coppice blocks of Tangoio willow, but that a week of exposure to the feed was required before intake peaked (Timmins 2000). Other studies (Kemp et al. 2001) have shown that the Tangoio willow has similar metabolisable energy and crude protein to maize silage (Densley et al. 2001) but has a slightly lower digestibility (65\% compared to $70 \%$ ) and a higher level of condensed tannins. These data suggest that the mulched trees can provide suitable supplementary fodder for the milking herd. Other work indicates other possible productivity benefits (Woodward et al. 1999; 2001) and anthelminthic effects (Hoskin et al. 2000) for stock fed on fodder with high condensed tannins.

In 2001/02 the whole trees were offered to the milking herd. The cows showed moderate interest in the tree feed offered, especially given that they had been offered turnips before the trees and also had ample amounts of pasture available late in the wet-summer milking season. Trees in the high-irrigation treatments during 2001/02 suffered an accumulation of effluent on the leaves once the trees grew tall enough to interfere with the throw of effluent from the $1.8 \mathrm{~m}$ high travelling irrigator. The cows rejected foliage from these treatments.

In the second year there was no build-up of effluent on the leaves because the trees were harvested before they became tall enough to interfere with the irrigation system. The trees were mulched and were then fed out to the cows using a silage wagon. Initially most of the cows showed considerable interest, probably because they assumed they were being offered silage. It seemed that after they realised that they were being offered mulched trees rather than silage, most of the cows lost interest in favour of pasture. However some of the cows maintained their interest and spent a considerable time eating the mulch. From this and other work (e.g. Timmins 2000) it is clear that it will be necessary to introduce the herd to mulched trees gradually.

\section{Conclusions}

The prospects for using coppiced blocks of willow and poplar for effluent control of dairy farms will depend on where, between the extremes seen to date, the longterm average growth rates fall. If, as we expect, the typical growth rates are nearer that measured in 2001/02, then it will be possible to apply more effluent to a coppice block than pasture without increasing the likelihood of leaching. This would reduce the amount of land required for the irrigation of effluent and would be an advantage on farms where the amount of land suitable for irrigation is limited (e.g. due to soil type or topography). Because the trees have a deeper rooting system than pasture, 
they could also have a role to play where wet weather storage of effluent is not practicable or where there are heightened concerns about the effects of nitrate leaching (e.g. the Lake Taupo catchment). Another advantage of the coppice blocks is that the trees accumulate a large amount of fodder with qualities (Kemp et al. 2001) similar to maize silage (Densley et al. 2001) that is available in late summer when many farms experience feed gaps. The fodder from coppice blocks may also have a place within organic production systems where the possible worming effects (Hoskin et al. 2000) could be useful.

\section{Acknowledgements}

This project is being supported by the MAF Sustainable Farming Fund, Fonterra, the Willow and Poplar Research Collective, Environment Waikato, and the Greater Wellington Regional Council.

\section{References}

Densley, R.; Miller, D.; Kolver, E.S. 2001. Breaking the feed barrier using maize silage. Proceedings of the New Zealand Grasslands Association 63: 289-293.

Elowson, S. 1999. Willow as a vegetation filter for cleaning of polluted drainage water from agricultural land. Biomass and Bioenergy 16: 281-290.

Guevara-Escobar, A.; Edwards, W.R.N.; Morton, R.H.; Kemp, P.D.; Mackay, A.D. 2000. Tree water use and rainfall partitioning in a mature poplar-pasture system. Tree Physiology 20: 97-106.

Heatley, P. 1995. Dairying and the environment - managing farm dairy effluent. Operational and design manual. Dairying and the Environment Committee of the New Zealand Dairy Board, Palmerston North, New Zealand.

Hoskin, S.O.; Wilson, P.R.; Barry, T.N.; Charleston, W.A.G.; Waghorn, G.C. 2000. Effect of forage legumes containing condensed tannins on lungworm (Dictyocaulus sp.) and gastrointestinal parasitism in young red deer (Cervus elaphus). Research in Veterinary Science 68: 223-230.

Kemp, P.D.; MacKay, A.D.; Matheson, L.A.; Timmins, M.E. 2001. The forage value of poplars and willows. Proceedings of the New Zealand Grasslands Association 63: $115-119$.

Logan, T.J. 1993. Agricultural best management practices for water pollution control: Current issues. Agriculture, Ecosystems \& Environment 46: 223-231.

Longhurst, R.D.; O’Connor, M.B.; Roberts, A.H.C.; Waller, J.E. 1999. Farm dairy effluent: Findings of recent research studies in the Waikato. pp. 273-282. In: Best soil management practices for production. Occasional Report No. 12. Eds. Currie, L.D.; Hedley, M.J.; Horne, D.J.; and Loganathan, P. Fertiliser and Lime Research Centre, Massey University, Palmerston North.

Oppong, S.K.; Kemp, P.D.; Douglas, G.B.; Foote, A.G. 2001. Browse yield and nutritive value of two Salix species and Dorycnium rectum in New Zealand. Agroforestry Systems 51: 11-21. 
Smith, M.; Allen, R.; Monteith, J.L.; Perrier, A.; Pereira, L.; Segeren, A. 1992. Expert consultation on revision of FAO methodologies for crop water requirements. Food and Agriculture Organisation of the United Nations (Land and Water Development Division), Rome. 60 pp.

Timmins, M.E. 2000. The incorporation of browse trees in the farm feed plan. Honours in Applied Science thesis, Massey University, Palmerston North, New Zealand.

Whitehead, D.C. 1995. Grassland nitrogen. CAB International, Wallingford, UK. $397 \mathrm{pp}$.

Wilkinson, A.G. 1999. Poplars and willows for soil erosion control in New Zealand. Biomass and Bioenergy 16: 263-274.

Williamson, J.C.; Taylor, M.D.; Torrens, R.S.; Vojvodic-Vukovic, M. 1998. Reducing nitrogen leaching from dairy farm effluent-irrigated pasture using dicyandiamide: a lysimeter study. Agriculture, Ecosystems \& Environment 69: 81-88.

Woodward, S.L.; Auldist, M.J.; Laboyrie, P.J.; Jansen, E.B.L. 1999. Effect of Lotus corniculatus and condensed tannins on milk yield and milk composition of dairy cows. Proceedings of the New Zealand Society of Animal Production 59: $152-155$.

Woodward, S.L.; Waghorn, G.C.; Ulyatt, M.J.; Lassey, K.R. 2001. Early indications that feeding lotus will reduce methane emissions from ruminants. Proceedings of the New Zealand Society of Animal Production 61: 23-26. 
